\title{
Geranium Uçucu Yağı ve Siprofloksasin ile Kombinasyonlarının Stapyhlococcus Aureus ve Esherichia Coli'ye Karşı Sinerjik Potansiyeli
}

\author{
Berrak DUMLUPINAR*
}

$\ddot{O} \mathbf{z}$

Amaç: Pelargonium graveolens bitkisinden elde edilen Geranium uçucu yağının, enfeksiyonların tedavisinde kullanılan kinolon grubu antibiyotiklerden biri olan siprofloksasin ile kombine edilerek, sik rastlanan hastane enfeksiyonu etkeni patojen mikroorganizmalara karşı antimikrobiyal etkilerinin in vitro deney modelinde gösterilmesi çalışmamızın temel amacını oluşturmaktadır.

Yöntem: P. graveolens uçucu yağının siprofloksasin ile kombinasyonlarının Staphylococcus aureus ve Escherichia colìye karşı antimikrobiyal aktiviteleri Minimal İnhibitör Konsantrasyon (MİK) saptama yöntemi ile tespit edildi. MİK değeri belirlenen örneklerin zamana bağlı öldürme yöntemi ile uçucu yağ ve antibiyotiğin bakterisidal etkisi dinamik olarak gösterildi. Geranium'un tek başına ve siprofloksasin ile kombinasyonlarının oluşturduğu bakteriyel dış zar hasarı $625 \mathrm{~nm}$ dalga boyunda U.V spektrofotometre ile analiz edildi.

Bulgular: Geranium+siprofloksasin kombinasyonlarında geranium ve siprofloksasin arasında sinerjistik etki gözlendi. Geranium+siprofloksasin kombinasyonu, sirasıyla $E$. coli ve $S$. aureus proliferasyonunda $\sim \% 87$ ve $\sim 78$ oranında azalma gösterdi. Zamana bağlı bakteri hücre sayısının tespitinde 24. saatte, siprofloksasin+geranium kombinasyonunun canlı hücre sayısını azalttığı tespit edilirken, geranium ve siprofloksasinin tek başına kullanımı kombinasyona kıyasla hücrelerin tam olarak yok edildiğini göstermedi. $E$. coli ve $S$. aureus için, siprofloksosasinin + geranium kombinasyonunun kullanıldı̆̆ı gruplarda, diğer gruplardan daha yüksek bakterisidal membran hasarı gözlendi.

Sonuç: Çalışmamızda, geranium yağının antimikrobiyal etkisi ile siprofloksasin ve siprofloksasin+geranium kombinasyonunun antimikrobiyal etkisi karşılaştırıldı. Buna göre siprofloksasin+geranium kombinasyonu hem geranium yağından hemde siprofloksasinden daha etkin bulundu.

Anahtar Kelimeler: Pelargonium graveolens, geranium yağı, siprofloksasin, antimikrobiyal aktivite.

\section{Synergic Potential of Geranium Essential Oil and Ciprofloxacin Combination Against on Staphylococcus Aureus and Escherichia Coli}

\begin{abstract}
Aim: The main purpose of our study is that Geranium essential oil obtained from Pelargonium graveolens plant is combined with ciprofloxacin, a quinolone antibiotic used in the treatment of infections, to reveal its antimicrobial effects against pathogenic microorganisms, which are common nosocomial infections, in an in vitro experimental model.

Methods: Antimicrobial activity of combinations of $P$. graveolens essential oil with antibiotic (ciprofloxacin) against Staphylococcus aureus and Escherichia coli was determined by the minimum

Özgün Araştırma Makalesi (Original Research Article)

Geliş / Received: 15.12 .2021 \& Kabul / Accepted: 23.12.2021

DOI: https://doi.org/10.38079/igusabder.1036988

${ }^{*}$ Sorumlu Yazar: İstanbul Gelişim Üniversitesi Sağlık Bilimleri Fakültesi, Beslenme ve Diyetetik Bölümü, İstanbul,

Türkiye, baltinsoy@gelisim.edu.tr ORCID https://orcid.org/0000-0002-0898-3043
\end{abstract}


inhibition concentration (MIC) detection method. The bactericidal effects of geranium oils and antibiotics were dynamically demonstrated by the time-dependent killing method of the samples. When geranium oil is used alone or in combination with ciprofloxacin, bacterial outer membrane damage was analyzed by U.V spectrophotometer at $625 \mathrm{~nm}$ wavelength.

Results A synergistic effect was observed between essential oil and essential oil+antibiotic combinations. Geranium+ciprofloxacin combination showed $\sim 87 \%$ and $\sim 78 \%$ reduction in E. coli and S. aureus proliferation, respectively. In the time-dependent determination of bacterial cell count, at 24 hours, the combination of ciprofloxacin + geranium was found to reduce the number of living cells, while the use of geranium and ciprofloxacin alone did not show complete destruction of cells compared to the combination. For E. coli and S. aureus, higher bactericidal membrane damage was observed in the groups where ciprofloxacin was used together with geranium oil than the other groups.

Conclusion: In this study, the antimicrobial effect of geranium oil, ciprofloxacin, and its combination were compared. Accordingly, the combination of ciprofloxacin + geranium oil was found to be more effective than both geranium oil and ciprofloxacin.

Keywords: Pelargonium graveolens, geranium oil, ciprofloxacin, antimicrobial activity.

\section{Giriş}

Enfeksiyon hastalıkları içerisinde modern tedavi yaklaşımları ve antibiyotik tedavi başarısı ortadadır. Antimikrobiyal ajanlarla bakteriyel enfeksiyonların neden olduğu ölümle sonuçlanan hastalıkların sayısında belirgin bir düşüş olmasına karşın, patojen kaynaklı hastalıkların oluşması günümüzde önemli bir sorun olmayı sürdürmektedir. Bu nedenle etkili ve hedefe yönelik tedavinin erken dönemde başlaması oldukça önemlidir ${ }^{1}$. Enfeksiyona neden olan patojenin bilinmediği zamanlarda antimikrobiyal spektrumun geniş olması, sadece tek antimikrobik ajanın diğer hastalık etkeni mikroorganizmalara etkili olmadığı enfeksiyon tedavisi, mikroorganizmanın antimikrobiyal ajana direnç geliştirme ihtimalinin azaltılması ve antimikrobiyallerin toksik etkisinin azaltılması gibi durumlar kombine antibiyotik kullanımının nedenlerindendir. ${ }^{2}$ Ancak antibiyotiklerin kombine kullanılmasının haklı gerekçeleri olduğu gibi, enfeksiyon hastalıklarının tedavilerinde antibiyotik kombinasyonlarının kullanımı mali açıdan yük getirmekte ayrıca bir yan etki ortaya çıktığında tedavi süresinin uzamasına da neden olmaktadır.

Bu çalışmadan elde ettiğimiz sonuçlara göre; ticari olarak satın alınan, Pelargonium graveolens türünden izole edilen geranium yağının, enfeksiyon tedavilerinde sıklıkla kullanılan kinolon grubu antibiyotik ile kombine edilmesi, Türkiye'de sık görülen hastane etkeni mikroorganizmaların direnç mekanizmalarına zarar vermiştir. Böylece kombine antibiyotik tedavisinde görülmesi muhtemel istenmeyen etkilerin ve maliyetin azaltılması mümkün olabilecektir. Bugün tartışılan, penisiline dirençli bakterilerin artışı bu bakterilerin yol açtığı enfeksiyonlarda tedavinin gerçekleşememesine neden olmaktadır. Bu nedenle, özellikle bakterilere dirençli suşların mücadelesine yönelik alternatif stratejilerin bulunması önemlidir. $\mathrm{Bu}$ çalışma ile hastane enfeksiyonu tedavilerinde kullanılan kinolon grubu bir antibiyotik olan siprofloksasin, bir fitokimyasal olan uçucu yağ ile kombine edilerek test edilerek denemiş; deney sonuçlarına göre, hem antimikrobik etkinin güçlendirilmesi hem de bakterilerin antibiyotik direnci geliştirmesini engellemek mümkün olabilmiştir.

Pereira ve ark., Eucalyptus globulus uçucu yağının gentamisin ile kombine kullanımının Pseudomonas aeruginosa'ya karşı antimikrobiyal etkisini araştırdıkları bir çalışmada; uçucu yă̆ ve antibiyotik kombinasyonlarının antimikrobiyal etkisi gentamisin ve uçucu yağın tek başına kullanılan etkisinden yüksek olduğunu bildirmişlerdir3. Polly ve ark., çeşitli ticari uçucu yağlar ile beta laktam antibiyotiklerin kombine kullanımının çoklu ilaç dirençli Esherichia coli suşlarına 
karşı olan antimikrobiyal etkisini araştırmışlar ve uçucu yağ +antibiyotik çiftlerinin sinerjistik etkilerini göstermişlerdir4. Literatür incelemelerimizde; Pelargonium türlerinden elde edilen uçucu yağların kinolon grubu antibiyotik ile kombine kullanımının $S$. aureus ve E.coli patojenleri üzerinde inhibe edici etkisine yönelik bir çalışmaya rastlamamamız, uçucu yă üzerinde yoğunlaşmamıza neden olmuştur. Bu çalışmada P. graveolens elde edilen uçucu yağın antibiyotik ile kombine edilerek sinerjistik bir etki ile, hastane enfeksiyonu etkeni patojenlere karşı antimikrobiyal etkisinin olup olmadığı ilk kez tespit edilmiştir. Bu cinsin Türkiye'de yetişen türü olan $P$. enlicherianum'un toprak üstü kısımlarından elde edilen metanol özütünün menenjit etkeni olduğu bilinen patojenlere karşı antimikrobiyal etkisi tarafımızdan incelenmiş ve sonuçlar umut verici olmuştur. P. enlicherianum'un \%70'lik metanol özütü $H$. influenzae, N. meningitidis, L. monocytogenes ve K. pneumoniae bakterilerine karşı sırasıly 18,5, 24,5, 14,5 ve 17,5 mm zon çapı vererek antimikrobiyal etkili bulunmuştur ${ }^{5,6}$. Bu verilere dayanarak; Geranium oil bileşenlerinin alkol ve aldehitlerce daha zengin oluşundan dolayı yüksek antimikrobiyal etki gösterdiği düşünülmektedir.

\section{Gereç ve Yöntem}

\section{P. graveolens Türünden Uçucu Yă̆ın Elde Edilmesi}

Çalışmamızda Geranium oil, Chinese (Sigma, MKBZ2472V) ticari yağı kullanıldı.

\section{Bakteri Kültürünün Hazırlanması}

Çalışmalarda kullanılan S. aureus ATCC 25923 ve E. coli ATCC 25922 Amerikan tipi kültür koleksiyonundan (ATCC) temin edildi. CLSI önerileri doğrultusunda, test edilen bakteriler gelişimleri için uygun olan Triptikaz Soy Agar (TSA) besiyerine pasajlanarak 24 saat, $37^{\circ} \mathrm{C}^{\prime} \mathrm{de}$ aerobik ortam şartlarında geliştirildikten sonra, kültürlerdeki kolonilerden, fizyolojik tuzlu su (FTS) (\% 0,9 NaCl) içinde McFarland 0.5 (yaklaşı 1 1x10 ${ }^{8} \mathrm{kob} / \mathrm{mL}$ ) olacak şekilde ile ayarlandı.

\section{Antibiyotik Çözeltilerinin Haztrlanması}

Çalışmamızda kullanılacak antibiyotikler aşağıdaki formüle göre hazırlandı:

Antibiyotik miktarı $(\mathrm{mg})=[$ İstenilen konsantrasyon $(\mu \mathrm{g} / \mathrm{mL})$ x Çözücü hacmi $(\mathrm{mL})] /[$ Antibiyotik Potensi $(\mu \mathrm{g} / \mathrm{mg})]$

\section{Uçucu Yă̆ Dilüsyonlarmmn Hazrlanması}

Uçucu yağ için gerçekleştirilen dilüsyon 100 olarak kabul edildi. Diğer konsantrasyonlar eşit oranda azaltıldı (\%50, \%25, \%12,5, \%6,25, \%3,13, \%1,56, \%o,78, \%o,39, \%o,20, \%0,10, \%o, o5, \% $0,025, \% 0,013$ ve $\% 0,007)^{3}$.

\section{Minimal İnhibitör Konsantrasyon (MİK) ile Antimikrobiyal Aktivite Tayini}

Antimikrobiyal aktivite tayininde uçucu yağ tek başına ve antibiyotiklerle kombinasyon halinde S. aureus ve E.colìye karşı test edildi. MİK tespiti Clinical and Laboratory Standarts Institute (CLSI 2012) antibiyotik duyarlılık standartlarına uygun olarak mikrodilüsyon yöntemi kullanılarak yapıldı. İnkübasyon süresi sonunda mikroplaklar spektrofotometrede $625 \mathrm{~nm}$ dalga boyunda ölçülerek her kuyucuk kontrol ile kıyaslanarak üremenin gözlenmediği en düşük konsantrasyon yani minimum inhibe edici konsantrasyon (Mİ) $\mu \mathrm{g} / \mathrm{mL}$ olarak belirlendi. Deneyler üç tekrarlı yapıldı. Sinerjistik etki FİKi̇ (fraksiyonel inhibitör konsantrasyon indeksi) doğrultusunda aşağıdaki formüle göre belirlendi`. 
FİK Uçucu Yağ = Antibiyotik varlı̆̆ında uçucu yağ MİK değeri / Tek başına uçucu yağ MİK değeri; FİK Antibiyotik = Antibiyotik varlığında antibiyotik MİK değeri / Tek başına antibiyotik MİK değeri; FİKİ = Uçucu yağ FİK değeri + Antibiyotik FİK değeri

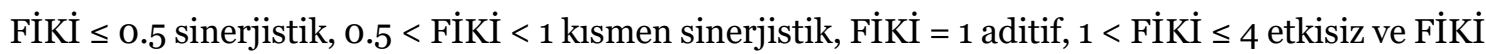
$>4$ antagonistik

\section{Zamana Bağh Öldürme Yöntemi}

Yap vd., 2015, metoduna göre zamana ve antibiyotik yoğunluğuna bağlı olarak uçucu yağ ve antibiyotiğin bakterisidal etkisi tespit edildi. Deney iki tekrarlı olarak gerçekleştirildi.

\section{Dıș Membran Geçirgenliğinin Belirlenmesi}

Geranium yağı ve siprofloksasin kombinasyonlarının bakterinin dış membranına verdiği hasar Hemaiswarya ve Doble ve Marri ve ark. yöntemlerine göre belirlendi3,8.

\section{Ístatiksel Yöntemler}

Sonuçların değerlendirilmesi Windows SPSS 13.0 programında tek yönlü varyans (One-Way ANOVA) analizi ve uygun post-hoc testler kullanılarak yapıldı. İkili grupların karşılaştırılması için Wilcoxon testi kullanıldı.

\section{Bulgular}

\section{Minimal İnhibitör Konsantrasyon (MİK) Zon Değerleri}

$125 \mu \mathrm{g} / \mathrm{mL}$ Geranium yağı sırasıyla $E$. coli ve $S$. aureus proliferasyonunda sirasıyla \%45 ve $\% 43$ oranında azalma sergilerken aynı konsantrasyonda siprofloksasin, E. coli ve $S$. aureus için $\sim \% 89$ hücre büyümesi inhibisyonlarına neden oldu. Geranium+siprofloksasin kombinasyonu, sirasiyla E. coli ve $S$. aureus proliferasyonunda $\sim \% 87$ ve $\sim \% 78$ oranında azalma gösterdi. Benzer şekilde, sirasiyla 31.25 ve $15.62 \mu \mathrm{g} / \mathrm{mL}$ Geranium+siprofloksasin kombinasyonu, $S$. aureus ( $\sim 58$ ve $\sim \% 46)$ ve $E$. coli ( \%64 ve $\% 57)$ hücre yoğunluğunda çok etkili azalma gösterdi. Bunlara ek olarak, siprofloksasin ve geranium+siprofloksasin minimal inhibitör konsantrasyon (MİK) değerleri, S. aureus ve E. coli için farklı inhibisyon yüzdeleriyle $3.91 \mu \mathrm{g} / \mathrm{mL}$ olarak belirlendi (Şekil 1-2).

Şekil 1. Siprofloksasin, Geranium yağı ve Geranium+Siprofloksasin kombinasyonunun E. colìye karşı MİK değerleri

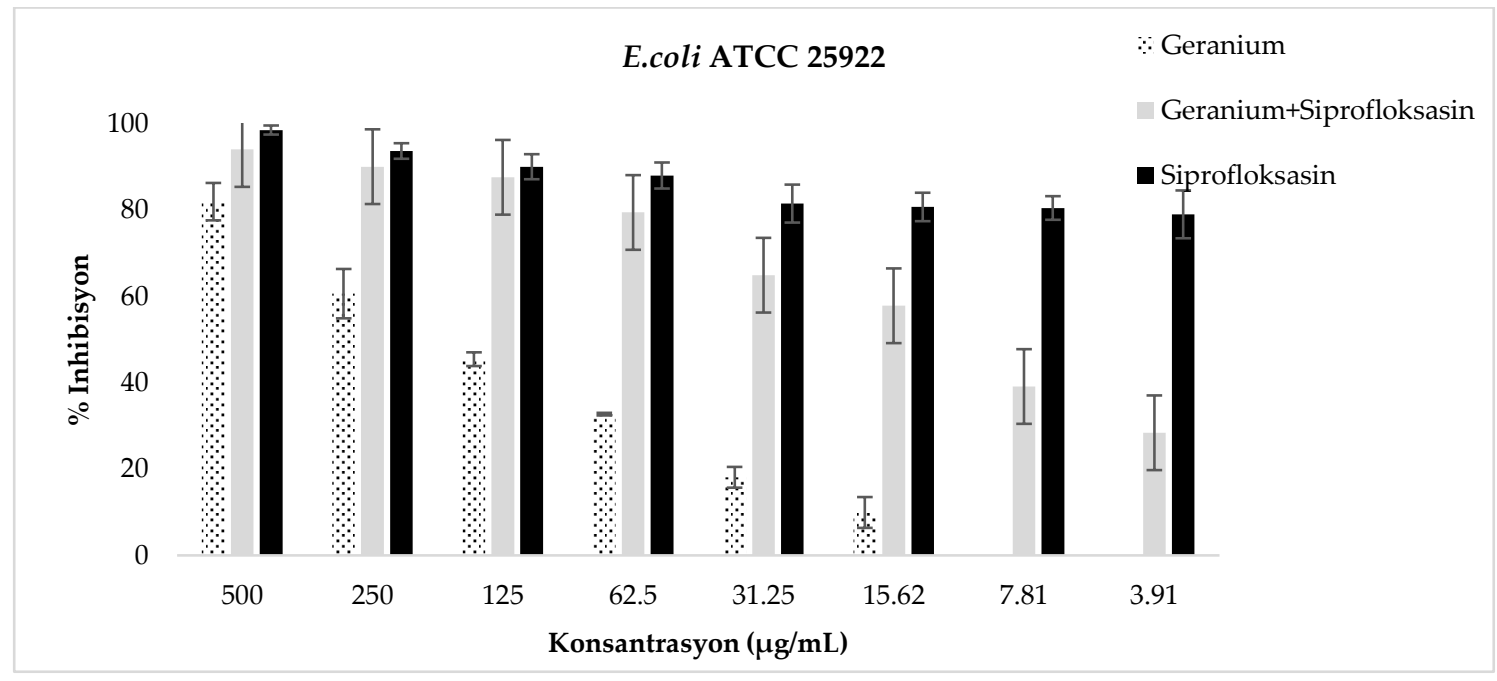


Şekil 2. Siprofloksasin, Geranium yağı ve Geranium+Siprofloksasin kombinasyonunun $S$. aureus'a karşı MİK değerleri

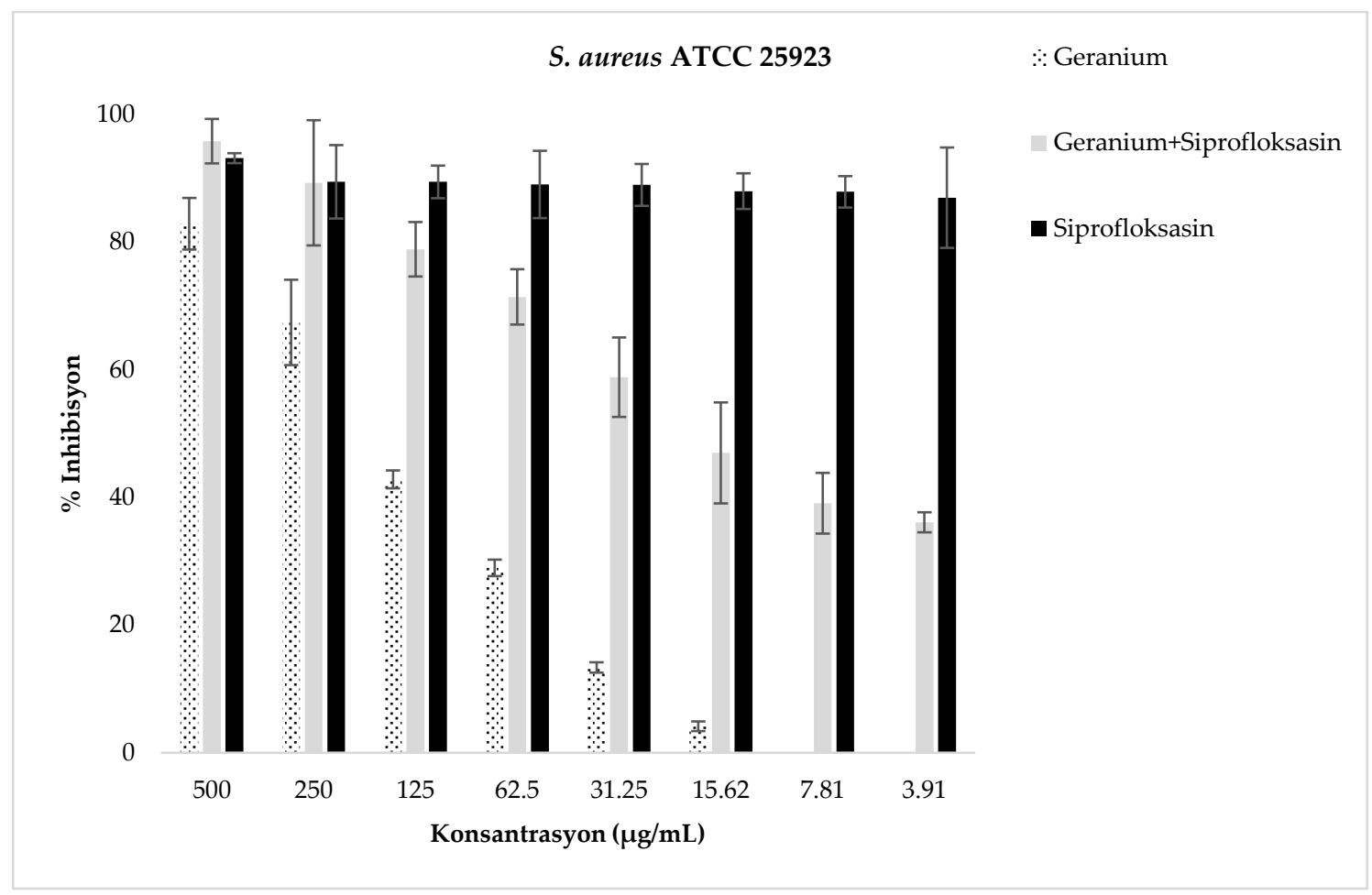

\section{Zamana Bă̆h Öldürme Yöntemi}

Geranium yağı ile siprofloksasin arasındaki bakterisid etkinin gözlendiği veriler Şekil 3-4.'te gösterilmiştir. Yaşayan bakteri sayısındaki değişimin zamanla nasıl değiştiğini gösteren çalışmada siprofloksasin ve uçucu yağ+siprofloksasin grupları arasında istatistiki olarak anlamlı sonuçlar bulunmadı. Tedavi sonrası 24. saatte, geranium yağı + siprofloksasin kombinasyonu sadece uçucu yağın tek başına kullanıldığı tedavi ile kıyaslandığında, canlı bakteri hücrelerinin inhibe olduğu tespit edildi. Sadece siprofloksasin kullanımı, hücre sayılarını önemli oranda azaltmadı. Siprofloksasin+geranium kombinasyonunun dışında sadece geranium ve siprofloksasinin tek başına kullanımı kombinasyona kıyasla hücrelerin tam olarak yok edildiğini göstermedi. 
Şekil 3. Geranium, siprofloksasin ve her ikisinin kombinasyonunun E. coli’ye karşı zamana bağlı öldürme analizi

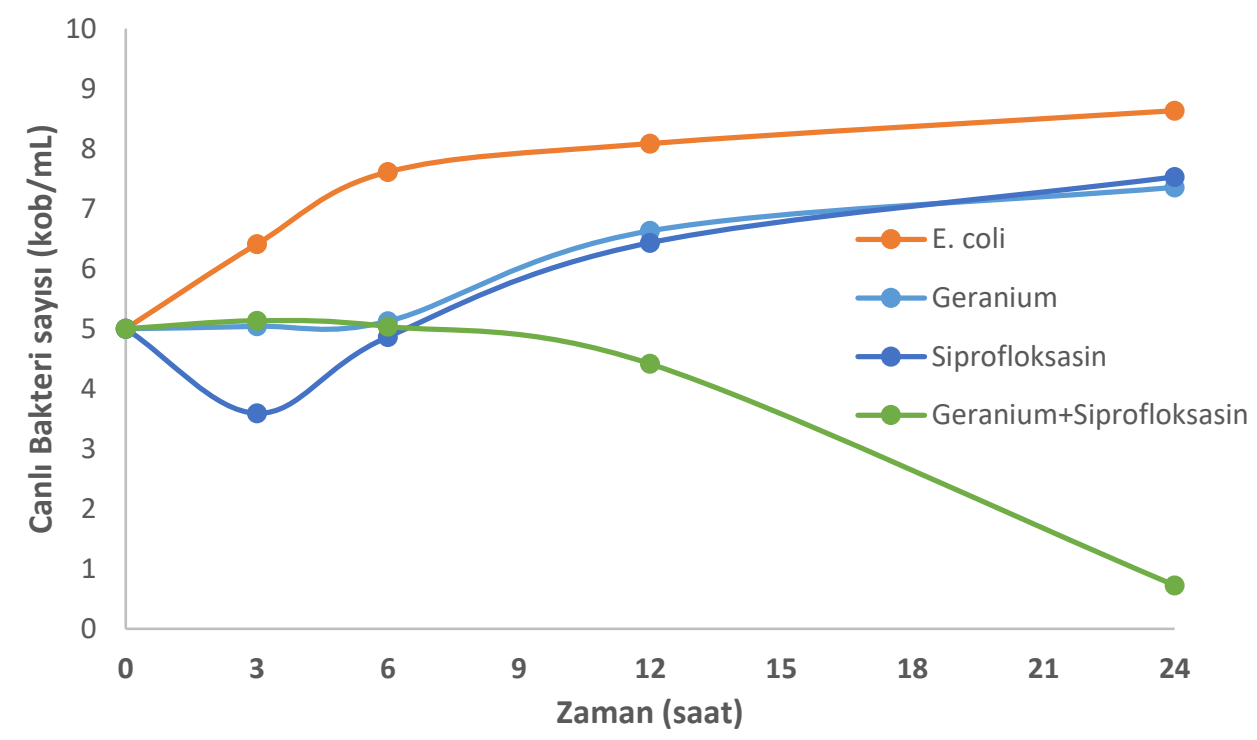

Şekil 4. Geranium, siprofloksasin ve her ikisinin kombinasyonunun S.aureus'a karşı zamana bağlı öldürme analizi

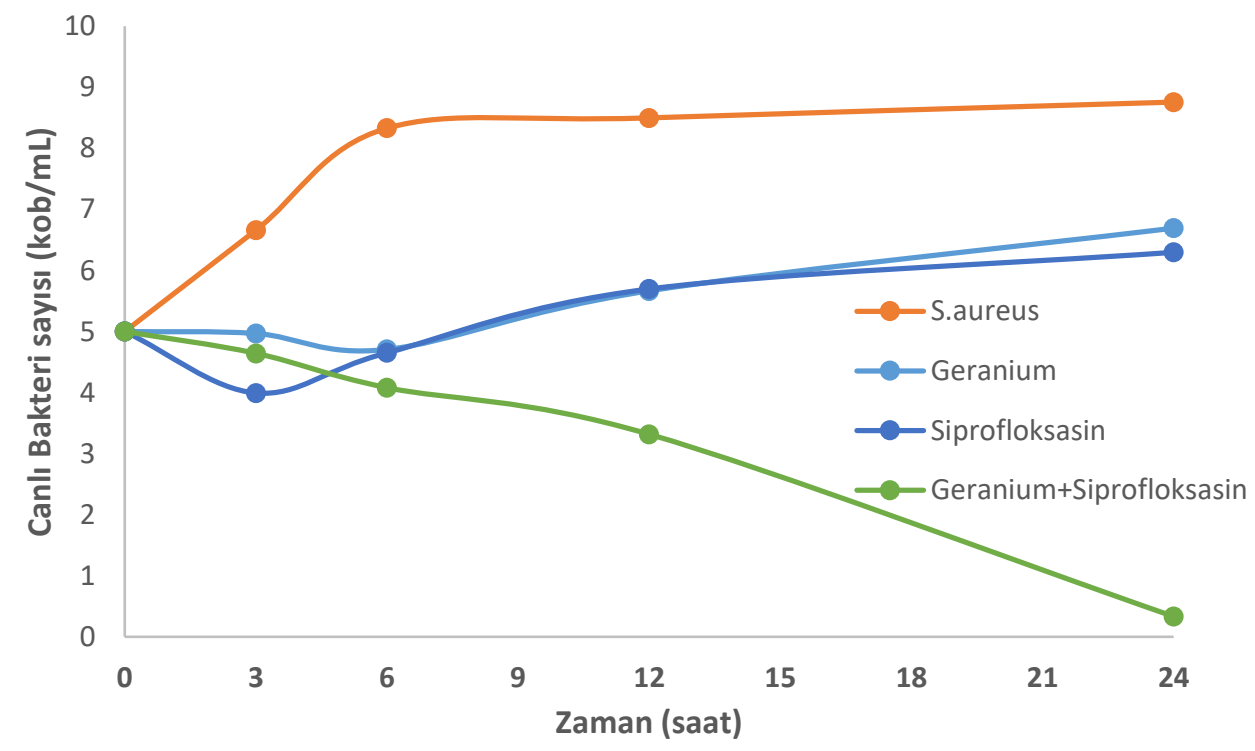

\section{Dış Membran Geçirgenliği}

0, 5., 10., 30. ve 60. dakikalarda SDS (Sodyum dodesil sülfat)'ın neden olduğu hızlı hücre ölümlerinin tespit edildiği absorbanslar arasındaki farklılıklar Tablo 1-2'de gösterilmişir. E. coli ve $S$. aureus için siprofloksosasinin geranium yağı ile kullanıldığı gruplarda diğer gruplardan anlamlı derecede daha yüksek bakterisidal membran hasarı gözlendi ve en az sağ kalım değerleri verdi $(\mathrm{p}<0,001)$. 
Tablo 1. Geranium, siprofloksasin ve Geranium+siprofloksasin kombinasyonu tarafindan E.colinnin dış zar hasarı

\begin{tabular}{|l|l|l|l|l|l|}
\hline $\mathbf{O D}_{\mathbf{6 2 5}}=$ SD (n=3) & 0 & 5 & 10 & $\mathbf{3 0}$ & $\mathbf{6 0}$ \\
\hline Zaman (dk) & & & & & \\
\hline $\begin{array}{l}\text { E. coli Kontrol) } \\
\text { \% o,1 SDS ile } \\
\text { \% o,1 SDSsiz }\end{array}$ & $0,31 \pm 0,009$ & $0,30 \pm 0,004$ & $0,29 \pm 0,012$ & $0,30 \pm 0,007$ & $0,30 \pm 0,013$ \\
\hline $\begin{array}{l}\text { Geranium (2o mg/L) } \\
\text { \% o,1 SDS ile } \\
\text { \% o,1 SDSsiz }\end{array}$ & $0,30 \pm 0,006$ & $0,33 \pm 0,003$ & $0,32 \pm 0,014$ & $0,29 \pm 0,002$ & $0,29 \pm 0,007$ \\
\hline $\begin{array}{l}\text { Siprofloksasin (3,91 } \boldsymbol{\mu g} / \mathbf{L}) \\
\text { \% o,1 SDS ile } \\
\text { \% o,1 SDSsiz }\end{array}$ & $0,31 \pm 0,012$ & $0,29 \pm 0,016$ & $0,29 \pm 0,016$ & $0,27 \pm 0,021$ & $0,26 \pm 0,021$ \\
\hline $\begin{array}{l}* \text { Geranium+Siprofloksasin } \\
\text { \% o,1 SDS ile } \\
\text { \% o,1 SDSsiz }\end{array}$ & $0,29 \pm 0,004$ & $0,27 \pm 0,001$ & $0,27 \pm 0,017$ & $0,26 \pm 0,002$ & $0,23 \pm 0,011$ \\
\hline
\end{tabular}

OD: Optik dansite, Dk: Dakika, mg/L: miligram/Litre ${ }^{*} \mathrm{p}<0,001 ;$ Siprofloksasin ile kıyaslandığında.

Tablo 2. Geranium, siprofloksasin ve Geranium+siprofloksasin kombinasyonu tarafindan $S$. aureus'un dış zar hasarı

\begin{tabular}{|c|c|c|c|c|c|}
\hline \multicolumn{6}{|l|}{$\mathrm{OD}_{625}=\mathrm{SD}(\mathrm{n}=3)$} \\
\hline Zaman (dk) & $\mathbf{O}$ & 5 & 10 & 30 & 60 \\
\hline \multicolumn{6}{|l|}{ S. aureus (Kontrol) } \\
\hline$\%$ o,1 SDS ile & $0,32 \pm 0,004$ & $0,30 \pm 0,006$ & $0,29 \pm 0,010$ & $0,28 \pm 0,007$ & $0,28 \pm 0,003$ \\
\hline$\%$ o,1 SDSsiz & $0,32 \pm 0,001$ & $0,32 \pm 0,003$ & $0,31 \pm 0,003$ & $0,31 \pm 0,012$ & $0,30 \pm 0,009$ \\
\hline \multicolumn{6}{|l|}{ Geranium (5 mg/L) } \\
\hline$\%$ o,1 SDS ile & $0,31 \pm 0,002$ & $0,28 \pm 0,006$ & $0,28 \pm 0,026$ & $0,28 \pm 0,001$ & $0,27 \pm 0,011$ \\
\hline$\%$ o,1 SDSsiz & $0,32 \pm 0,006$ & $0,30 \pm 0,014$ & $0,29 \pm 0,009$ & $0,28 \pm 0,011$ & $0,27 \pm 0,018$ \\
\hline \multicolumn{6}{|l|}{ Siprofloksasin $(3,91 \mu \mathrm{g} / \mathrm{L})$} \\
\hline$\%$ o,1 SDS ile & $0,28 \pm 0,004$ & $0,27 \pm 0,009$ & $0,26 \pm 0,007$ & $0,25 \pm 0,012$ & $0,22 \pm 0,008$ \\
\hline$\%$ o,1 SDSsiz & $0,28 \pm 0,011$ & $0,28 \pm 0,02$ & $0,27 \pm 0,005$ & $0,26 \pm 0,022$ & $0,23 \pm 0,014$ \\
\hline \multicolumn{6}{|l|}{${ }^{*}$ Geranium+Siprofloksasin } \\
\hline$\%$ o,1 SDS ile & $0,26 \pm 0,017$ & $0,24 \pm 0,022$ & $0,24 \pm 0,003$ & $0,23 \pm 0,011$ & $0,20 \pm 0,011$ \\
\hline \% o,1 SDSsiz & $0,28 \pm 0,01$ & $0,27 \pm 0,009$ & $0,26 \pm 0,009$ & $0,24 \pm 0,021$ & $0,21 \pm 0,004$ \\
\hline
\end{tabular}

OD: Optik dansite, Dk: Dakika, mg/L: miligram/Litre ${ }^{*} \mathrm{p}<0,001 ;$ Siprofloksasin ile kıyaslandı ̌̆ında.

\section{Tartışma}

Günümüzde çoklu dirençli organizmaların görülme sıklığı artmakta ve bu durum küresel bir sorun haline gelmektedir. Antibiyotiklere direnç arttıkça, enfeksiyon kontrolünün önemi de artmaktadır. Enfeksiyon tedavilerinde antibiyotik kombinasyonları sık kullanılan tedavi yöntemleridir. Ancak sefoksitin gibi beta-laktamaz indüksiyonuna yol açan bir antibiyotiğin bir beta-laktam antibiyotik ile kombine edilmesi, beta-laktamın parçalanmasına neden olabileceğinden iki beta-laktam antibiyotiğin birlikte verilmesi sakıncalı durumlara neden olabilir. Aminoglikozit+sefalosporin kombinasyonlarında aminoglikozitler ile sefalosporinler kimyasal etkileşime girerek birbirlerini inaktive edebilir ${ }^{2}$. Bir diğer sorun ise bakterisidal ve bakteriyostatik antibiyotiği bir arada vererek antibiyotiğin letal etkisinin kaybolabilme ihtimalidir9-11. Bununla birlikte, bu antibiyotiklere direnç artmakta ve bu durum yeni antibiyotiklerin aranmasına neden olmaktadır. İn vitro çalışmamızda elde ettiğimiz sonuçlar, bakterisidal etkili kinolon grubu antibiyotik olan siprofloksasin ile Geranium uçucu yağının 
kombine edilerek kullanılmasının, Türkiye'de hastane enfeksiyonlarının en yaygın etkeni olduğu bilinen $S$. aureus ve $E$. coli patojenlerinin kontrolünü olumlu yönde etkileyerek, bu uçucu yağın doğal bir ajan olarak faydalı olabileceğini göstermektedir.

Pelargonium türünden çeşitli uçucu yağlar sentezlenmiştiri². Bitkinin yaprak, gövde ve yaprak sapında yüksek kalitede yağ bulunur ${ }^{13}$. Pelargonium graveolens bitksinden elde edilen geranium uçucu yağında yüksek oranda sitronelol ( \%29), geraniol ( \%12), delta-selen ( \%9) ve sitronelil format ( \%7) ana bileşenler olarak bulunmuştur ${ }^{14}$. Geranium uçucu yağındaki bu bileşiklerin yağın antimikrobiyal aktivitesi ile ilişkili olabileceği düşünülmektedir. Daha önceki çalışmalarda sitronelol ve geraniol'ün yüksek antimikrobiyal ve antifungal aktiviteleri gösterilmiştir ${ }^{15,16}$.

Bu çalışmada, $S$. aureus ve $E$. coli’nin etken olduğu enfeksiyonların tedavilerinde kullanılan siprofloksasin antibiyotiğinin bu patojenler üzerinde etki mekanizması geranium uçucu yağı ile kombinasyon halinde daha da genişleyerek ve siprofloksasinin etkinliğinin artmasiyla sonuçlanmıştır. Gram negatif bakterilerde, hidrofilik porinler, kimyasal yapılarına bağlı olarak diş zardan geçen moleküllerin düzenlenmesinden sorumludur. Hidrofobik maddelerin dışlanması çoğu zaman hücrelerin dışında meydana gelir ve muhtemelen lipopolisakarit katmanını parçalayan moleküller tarafından dış zarın zayıflamasına neden olur; bu ajanlar genellikle membran geçirgenleştiricileri olarak biliniripi,18. Membran hasarının tespiti ile dış zar bariyerinin, uçucu yağın varlığı ile bozulduğu ve siprofloksasinin, membranın dış yüzeyinde yerleştiği gösterilmiştir (Macheboeuf, 2006). Yapılan çalışmalar uçucu yağların bakteri hücre zarınıda birikerek asitlik düzeyini arttırdığını ileri sürmektedir.

Uçucu yağların Gram pozitif bakteriler üzerinde Gram negatiflere kıyasla daha fazla antimikrobiyal aktivite gösterdiği, yapılan çalışmalarda bildirilmiştirir,20. Uçucu yağların çeşitli polifenolik bileşik içermeleri, bu fenollerin lipofilik özellikte olmaları ve hücre içine sızma kabiliyetinde olmaları nedeniyle bakteri hücre membranını geçerek bakterinin ölümüne neden olabilirler ${ }^{21}$.

Zamana bağlı öldürme çalışmalarının sonuçları, uçucu yağ ve antibiyotikler arasında sinerjistik bir etki olduğunu ve bu yüzden sadece uçucu yağ ve/veya sadece antibiyotiklerle yapılan tedavilere kiyasla daha fazla etkili olduğunu göstermektedir. Hem $S$. aureus hem de $E$. coli için uçucu yağ+antibiyotik kombinasyonları 6. saatten itibaren canlı hücre sayısında önemli ölçüde hızlı bir azalmaya neden olmuştur.

Geleneksel antimikrobiyal ajanlar ve uçucu yağlar arasındaki kombinasyon yeni bir oluşumdur. Bazı uçucu yağlar, tek başlarına kullanıldığında önemli herhangi bir önleyici etki göstermemesine rağmen, bunların sinerjik etkili olduğu bulunmuştur. Standart ilaçlarla kombinasyon halinde kullanıldığında, kombinasyon etkisi kendi performanslarını aşar ve gelişmiş antimikrobiyal aktivite gösterir22.

\section{Sonuç}

Çalışmamızda tek başına uçucu yağın standart mikroorganizmalara karşı etkisi tek başına anitibiyotiğin kullanımından daha az etkiliyken uçucu yağın antibiyotikler ile yapılan kombinasyonlarının aynı standart mikroorganizmalara karşı çok daha etkili olduğu gösterilmiştir. Elde edilen sonuçlara göre, geranium uçucu yağının sitronelol ve geraniol bileşiklerinin ve uçucu yağın yapısındaki polifenollerin etkisi ile siprofloksasin antibiyotiğinin antimikrobiyal etkisini artırma kapasitesini gösterdi. Özellikle hastane enfeksiyonları başta olmak üzere $E$. coli ve $S$. aureus'un neden olduğu bazı bulaşıcı hastalıkların klinik yönetiminde antibiyotiklerle kombinasyon halinde faydalı olabilir. Bununla birlikte, bu yağın toksisitesi ve 
klinik uygulamalar için optimal konsantrasyonların belirlenmesi hakkında tam bir görüşe sahip olmak için gelecekte daha fazla araştırma yapılmalıdır.

\section{KAYNAKLAR}

1. Kanra G, Ceyhan M, Kara A. Menenjit III: Tedavi. Çocuk Sağh̆ğı ve Hastalıkları Dergisi. 2003;46:217-223.

2. Ayaz C. Antibiyotik Kombinasyonları, Klimik Dergisi. 2001;14(3):140-143.

3. Pereira V, Dias C, Vasconcelos MC, Rosa E, Saavedraa MJ. Antibacterial activity and synergistic effects between Eucalyptus globulus leaf residues (essential oils and extracts) and antibiotics against several isolates of respiratory tractinfections (Pseudomonas aeruginosa), Industrial Crops and Products. 2014;52:1-7.

4. Yap PSX, Lim SHE, Hu CP, Yiap BC. Combination of essential oils and antibiotics reduce antibiotic resistance in plasmid-conferred multidrug resistant bacteria, Phytomedicine. 2013:20;710-713.

5. Dumlupinar B, et al. Synergic potential of Pelargonium endlicherianum Fenzl. Essential oil and antibiotic combinations against Klebsiella pneumoniae. South African Journal of Botany. 2020:135;117-126.

6. Dumlupinar B, et al. Synergy between Pelargonium endlicherianum essential oil and conventional antibiotics against Neisseria meningitidis and Haemophilus influenzae. South African Journal of Botany. 2022:146;243-253.

7. Yap PSX, Krishnan T, Chan KG, Lim SHE. Antibacterial mode of action of cinnamomum verum bark essential oil, alone and in combination with piperacillin, against a multi- drugresistant escherichia coli strain, J. Microbiol. Biotechnol. 2015;25(8):1299-1306.

8. Davis PH, Hedge IC. Pelargonium L'Hérit In: Flora of Turkey and the East Aegean Islands. Edinburgh: University Press; 1967:2;487-9.

9. Ceyhan M, Yildirim I, Balmer P, et al. A prospective study of etiology of childhood acute bacterial meningitis. Emerging Infectious Disease, 2008;14(7):089-1096.

10. Techasaensiri C, Messina AF, Katz K, Ahmad N, Huang R, McCracken GH Jr. Epidemiology and evolution of invasive pneumococcal disease caused by multidrug resistant serotypes of 19A in the 8 years after implementation of pneumococcal conjugate vaccine immunization in Dallas, Texas. Pediatric Infectious Disease Journal. 2010;29(4):294-300.

11. Özsürekci Y. Türkiye'de Menenjite Neden Olan Bakteriyel Ajanlar ve Meningokokal Serogrupların Seroprevalansı. [yan dal uzmanlık tezi]. Ankara: Çocuk Sağlığı ve Hastalıkları Anabilim Dalı, Hacettepe Üniversitesi, Tıp Fakültesi; 2013.

12. Lis-Balchin M. Geranium oil. International Journal of Aromatherapy 1996;7:18-20

13. Lis-Balchin M. Geranium and Pelargonium. UK, London: Taylor \& Franchis Group; 2002;116:1-3.

14. Abouelatta AM, Keratum AY, Ahmed SI. et al. Repellent, contact and fumigant activities of geranium (Pelargonium graveolens L.'Hér) essential oils against Tribolium castaneum (Herbst) and Rhyzopertha dominica (F.). Int J Trop Insect Sci. 2020:40;1021-1030 https://doi.org/10.1007/s42690-020-00161-4. 
15. Verma Ram S, et al. Chemical composition and antimicrobial activity of Java citronella (Cymbopogon winterianus Jowitt ex Bor) essential oil extracted by different methods. Journal of Essential Oil Research. 2020:449-455.

16. Lira, Maria Helena Pereira de, et al. Antimicrobial activity of geraniol: An integrative review. Journal of Essential Oil Research. 2020:187-197.

17. Borges A, Ferreira C, Saavedra MJ, Simoes M. Antibacterial activity and mode of action of ferulic and gallic acids against pathogenic bacteria. Microbial Drug Resistance. 2013:19;256-265.

18. Vaara M. Agents that increase the permeability of the outer membrane. Microbiology Reviews. 1992:56;395-411.

19. Luqman S, Dwivedi GR, Darokar MP, Kalra A, Khanuja SP. Potential of rosemary oil to be used in drug-resistant infections. Altern Ther Health Med. 2007;13(5):54-9.

20. Su JY, Zhu L, Tian YJ. Chemical composition and antimicrobial activities of essential oil of Matricaria songarica. International Journal of Agricultural Biology. 2012;14(1):107-10.

21. Hemaiswarya S, Doble M. Synergistic interaction of eugenol with antibiotics against Gram negative bacteria. Phytomedicine. 2009;16(11):997-1005. https://doi.org/10.1016/j.phymed.2009.04.006.

22. Gibbons S, Oluwatuyi M, Veitch NC, Gray AI. Bacterial resistance modifying agents from Lycopus europaeus. Phytochemistry. 2003;62(1):83-7. 